\title{
Fruit-removal Time Influences Return Bloom in Pecan
}

\author{
William Reid ${ }^{1}$ \\ Pecan Experiment Field, Kansas State University, Chetopa, KS 67336-0247 \\ Susan M. Huslig ${ }^{2}$, Michael W. Smith ${ }^{3}$, Niels O. Maness ${ }^{4}$, and \\ Julia M. Whitworth ${ }^{4}$ \\ Department of Horticulture and Landscape Architecture, Oklahoma State \\ University, Stillwater, OK 74078
}

Additional index words. Carya illinoinensis, alternate bearing

\begin{abstract}
The optimum time for removing pecans [Carya illinoinensis (Wangenh.) $\mathrm{K}$. Koch] to enhance return bloom was determined. Fruit were removed from part of 'Mohawk', 'Giles', and 'Gormely' trees five times during the season as determined by fruit phonological age: immediately after postpollination drop, at $50 \%$ ovule expansion, at $100 \%$ ovule expansion or water stage, during the onset of dough stage, and 2 weeks after dough stage. Return bloom of all cultivars was increased by fruit removal during ovule expansion. Removing 'Mohawk' and 'Giles' fruit shortly after pollination induced the greatest return bloom. Return bloom in the small-fruited 'Gormely' was equally stimulated by fruit removal at any time during ovule expansion, a result indicating that early fruit removal may be more important for large- than for small-fruited cultivars. If a commercially feasible method to thin pecans is developed, our studies indicate that the optimum time for fruit thinning would be during ovule expansion.
\end{abstract}

Pecan trees tend to bear alternately or irregularly (Wood, 1991). An excessive fruit load one year precedes a year of little or no crop. Pecan growers suffer economic losses in "on" and "off' years. During "on" years, overcropping results in poor nut fill and kernel quality, often to the point of making the nuts unmarketable (Reid, 1986). Further, overcropping reduces cold hardiness, often leading to shoot dieback or tree death (Smith and Cotten, 1985; Wood, 1986). Economic returns from low yields during "off' years frequently do not offset production and harvesting costs.

Depletion of carbohydrate reserves by a heavy crop load may be the sole trigger for alternate bearing in pecan (Davis and Sparks, 1974). Wood (1991) hypothesized that, without sufficient carbohydrates, a pecan terminal may not be able to initiate female flowers. A more complex regulatory mechanism for flower initiation that involves a threshold level of storage carbohydrates and the appropriate balance of endogenous phytohormones has been proposed (Smith et al., 1986; Wood, 1991). Wood (1991) argued that endogenous growth regulators are involved in distillate flower initiation but questioned their impor-

Received for publication 10 Aug. 1992. Accepted for publication 19 Mar. 1993. Contribution 93-55-J from the Kansas Agricultural Experiment Station and J6289 from the Oklahoma Agricultural Experiment Station. We thank Robert Berkemeyer for his cooperation during part of this study. The cost of publishing this paper was defrayed in part by the payment of page charges. Under postal regulations, this paper therefore must be hereby marked advertisement solely to indicate this fact.

'Research Horticulturist.

${ }^{2}$ Graduate Research Assistant.

${ }^{3}$ Professor.

${ }^{4}$ Assistant Professor. tance compared to carbohydrate supply. Although the question of how a pecan crop influences return bloom is still to be resolved, it is clear that heavy cropping inhibits the subsequent season's distillate flower production.

Mechanically thinning a heavy pecan crop during the late liquid endosperm stage of kernel development has improved 'Mohawk' and 'Shoshoni' fruit quality (Smith and Gallott, 1990). In the same study, 'Shoshoni' return bloom was improved by mechanical fruit thinning, while that of 'Mohawk' was not affected. Removing 'Stuart' fruit during the early dough stage of kernel development slightly improved return bloom (Sparks and Brack, 1972). While fruit removal has shown some promise as a means to reduce alternate bearing in pecan, the optimum fruit-removal time has not been established. This study was initiated to help define the optimum fruitremoval time.

We studied the influence of fruit-removal time on return bloom of pecan by conducting a series of experiments from 1988 through 1991. Although the site, type of data collected, and experimental design differed from year to year, treatments for all experiments were identical. We removed fruit at five times during the season as determined by fruit phonological age: immediately following postpollination drop, at $50 \%$ ovule expansion, at $100 \%$ ovule expansion or water stage (liquid endosperm), during the onset of dough stage (deposition of cotyledonary storage carbohydrates), and 2 weeks after the onset of dough stage. Treatments consisted of removing all fruit from an experimental unit by hand. A treatment in which all fruit were retained served as a check. To time treatments on a phonological scale, fruit development was monitored by collect- ing 20 fruit weekly from each of two trees adjacent to the trees from which fruit were being removed. Each fruit was dissected and rated for percent full ovule expansion, percent kernel development, and percent shuck dehiscence.

All studies involved applying two or more treatments to a single tree. We used this 'split-tree' technique to help separate the effectsof seedling rootstock variation from treatment effects. Rootstock can influence alternate bearing (Sitton and Dodge, 1938; Wood, 1989) and has been linked to genetic differences in carbohydrate storage capacity among rootstock (Wood, 1989). The split-tree approach has been used successfully in studies of alternatebearing in other fruit trees (Monselise and Goldschmidt, 1982) and was proposed as a viable method for pecan (Wood, 1991). In pecan, radiographic studies indicated that carbohydrate translocation and redistribution is restricted such that major limbs within a mature tree are independent of the tree as a whole (Lockwood-and Sparks, 1978).

All trees used in these experiments received recommended levels of pesticides and fertilizers (Reid, 1992b; Taylor et al., 1992; von Broembsen et al., 1992). All data collected in these experiments were analyzed using SAS (1988) to calculate means \pm SE. The GLM procedure (SAS, 1988) was used to perform an analysis of variance and to identify treatment differences with the protected least significant difference.

In 1988, five 'Mohawk' pecan trees were selected from a commercial pecan orchard near Adair, Okla. Trees were uniform in size (average trunk diameter $=32.2 \mathrm{~cm})$ and $\approx 95 \%$ of their shoots was bearing distillate flowers. Six similarly sized limbs (average diameter $=$ $8.6 \mathrm{~cm}$ ) were selected on each tree to receive the five fruit-removal treatments and serve as the check in this randomized complete-block experiment. Twenty-five fruiting shoots, each supporting four fruit, were tagged on each limb after postpollination fruit drop. Fruitremoval dates were 13 June, 8 Aug., 22 Aug., 12 Sept., and 26 Sept. 1988. Treatment effects were evaluated the following season. The number of flowers and new shoots produced by tagged shoots was counted on 31 May 1989, and the number of fruit set was counted on 15 June 1989.

In 1989,15 'Giles' pecan trees were selected from an orchard on the Pecan Experiment Field, near Chetopa, Kan. Trees were uniform in size (average trunk diameter $=26.1$ $\mathrm{cm}$ ), and $\approx 90 \%$ of their shoots was bearing distillate flowers. Four equally sized limbs (average diameter $=8.2 \mathrm{~cm}$ ) were selected on each tree to serve as the experimental units. Four of the six treatments were applied to each tree in a balanced incomplete-block experimental design (Cochran and Cox, 1957); each treatment was replicated 10 times.

Twenty-five fruiting shoots, each bearing three fruit, were tagged. on each limb. Fruitremoval dates were 21 June, 1 Aug., 22 Aug., 5 Sept., and 19 Sept. 1989. The number of flowers and new shoots produced by tagged shoots was counted on 23 May 1990, and the 
number of fruit set was counted on 20 June 1990.

In 1990, fifteen 19-year-old 'Gormely' pecan trees were selected from an orchard on the Oklahoma State Univ. Horticultural Research Farm near Stillwater. About $85 \%$ to $90 \%$ of the shoots bore an average of three fruit per cluster. Half of each tree received the fruit-removal treatments, while the other half served as the fruit-bearing check. A split-plot design was used for this experiment, with fruit-removal time as the main plot and defruited vs. bearing as the subplot. Each fruit-removal treatment was replicated three times. Fruit-removal dates were 27 May, 6 Aug., 30 Aug., 7 Sept., and 21 Sept. 1990. Twenty-five fruiting and 25 vegetative shoots were tagged at fruit-removal time on defruited and bearing sides of each tree to evaluate subsequent flowering. Flowers and shoots arising from the tagged shoots were counted on 10 May 1991.

The number of fruiting shoots and fruit set in 'Mohawk' and 'Giles' increased as a result of fruit removal during ovule expansion (Table 1). Fruit removal during postpollination stimulated the greatest amount of return bloom and fruit set. Once kernel deposition began, fruit removal had no influence on return bloom. The number of new shoots produced by each terminal branch was not influenced by the previous season's fruit-removal treatments (data not shown).

'Mohawk' and 'Giles' distillate flower production, even on limbs receiving the earliest fruit-removal treatment, was below the level needed to produce a full crop the following year. Extremely low temperatures $(-24 \mathrm{C}$ on 12 Dec. 1988 and -29 C on 20 Dec. 1989) injured the cambium of 'Mohawk' and 'Giles' during the winter after fruit removal treatments. Cold injury can weaken spring shoot growth (Wood, 1986) and decrease subsequent distillate flower production (Reid, 1992a).

Removing fruit at any stage of fruit development increased return bloom of 'Gormely' fruiting shoots on the defruited side of the tree compared to the bearing side (Table 2). Removing fruit before dough stage promoted the greatest return bloom of fruiting shoots on the defruited side. If fruit on the defruited side were allowed to complete kernel development, return bloom of fruiting and vegetative shoots on the bearing side of the tree was depressed. In general, vegetative shoots initiated more distillate flowers during the following year than adjacent fruiting shoots on the same side of the tree, regardless of fruit-removal treatment.

These results indicate that the fruiting status of individual shoots and the entire tree influences return bloom. Return bloom was greatest on shoots that did not fruit the previous season or from which fruit were removed during ovule expansion. In addition, removing fruit from half of the tree during ovule expansion improved return bloom on both sides of the tree, a result indicating a whole-tree effect. This intra-tree effect was not detected by Davis and Sparks' (1974) radiographic studies.

Table 1. Influence of fruit removal time on the number of fruiting shoots and fruit set (means \pm SE) on 'Mohawk' and 'Giles' pecan the year after fruit removal.

\begin{tabular}{lcr}
\hline $\begin{array}{l}\text { Fruit development stage } \\
\text { at time of fruit removal }\end{array}$ & $\begin{array}{c}\text { Flowering shoots/ } \\
\text { l-yr-old shoot }\end{array}$ & $\begin{array}{c}\text { Fruit/ } \\
\text { terminal }\end{array}$ \\
\hline Mohawk & & $1.44 \pm 0.15$ \\
Postpollination & $0.59 \pm 0.05$ & $0.97 \pm 0.15$ \\
One-half ovule expansion & $0.43 \pm 0.05$ & $1.05 \pm 0.14$ \\
Full ovule expansion & $0.39 \pm 0.05$ & $0.23 \pm 0.08$ \\
Dough stage & $0.10 \pm 0.04$ & $0.05 \pm 0.04$ \\
Two weeks after dough stage & $0.04 \pm 0.02$ & $0.00 \pm 0.00$ \\
Shucksplit & $0.00 \pm 0.00$ & 0.36 \\
LSD & 0.15 & $1.20 \pm 0.06$ \\
Giles & & $0.99 \pm 0.06$ \\
Postpollination & $0.44 \pm 0.02$ & $1.01 \pm 0.06$ \\
One-half ovule expansion & $0.33 \pm 0.02$ & $0.35 \pm 0.06$ \\
Full ovule expansion & $0.36 \pm 0.02$ & $0.18 \pm 0.06$ \\
Dough stage & $0.13 \pm 0.02$ & $0.04 \pm 0.06$ \\
Two weeks after dough stage & $0.06 \pm 0.02$ & 0.14 \\
Shucksplit $_{\text {LSD }}(0.05)$ & $0.01 \pm 0.02$ & 0.07 \\
\hline
\end{tabular}

Table 2. Influence of fruit removal time on the return bloom of fruiting and vegetative shoots on 'Gormely' pecan trees (means $\pm \mathrm{sE}$ ). Fruit were removed at selected times on half of the tree (defruited) and retained on the other half (bearing).

\begin{tabular}{|c|c|c|c|c|}
\hline \multirow{3}{*}{$\begin{array}{l}\text { Fruit development stage } \\
\text { at time of fruit removal }\end{array}$} & \multicolumn{4}{|c|}{ Pistillate flowers/1-yr-old shoot (no.) } \\
\hline & \multicolumn{2}{|c|}{ Fruiting shoots } & \multicolumn{2}{|c|}{ Vegetative shoots } \\
\hline & Bearing & Defruited & Bearing & Defruited \\
\hline Postpollination & $3.1 \pm 0.2$ & $5.7 \pm 0.3$ & $6.5 \pm 0.4$ & $6.0 \pm 0.4$ \\
\hline One-half ovule expansion & $3.5 \pm 0.2$ & $5.3 \pm 0.2$ & $6.1 \pm 0.4$ & $6.9 \pm 0.5$ \\
\hline Full ovule expansion & $3.8 \pm 0.2$ & $5.5 \pm 0.3$ & $7.4 \pm 0.4$ & $6.0 \pm 0.4$ \\
\hline Dough stage & $3.5 \pm 0.2$ & $4.4 \pm 0.2$ & $5.0 \pm 0.3$ & $5.7 \pm 0.3$ \\
\hline Two weeks after dough stage & $1.8 \pm 0.2$ & $2.8 \pm 0.2$ & $3.6 \pm 0.3$ & $3.3 \pm 0.2$ \\
\hline $\operatorname{LSD}_{(0.05)}$ same time of fruit removal & \multicolumn{4}{|c|}{0.94} \\
\hline $\mathbf{L S D}_{(0.05)}$ different times of fruit removal & \multicolumn{4}{|c|}{1.76} \\
\hline
\end{tabular}

Fruit-removal treatments did not influence the number of new shoots produced by shoots that were either vegetative or fruiting the previous season (data not shown). However, vegetative shoots produced more new shoots the following year than fruiting shoots, regardless of fruit removal.

Alternate bearing in many fruit tree species can be moderated by removing part of the crop during "on" years (Monselise and Goldschmidt, 1982). If fruit thinning is to reduce alternate bearing in pecan, our studies indicate that fruit must be thinned during ovule expansion. In apple (Malus domestics Borkh.), fruit thinning during, or shortly after, bloom promotes the greatest return bloom (Williams, 1979). We found that 'Mohawk' and 'Giles' pecan trees behave similarly, with the greatest return bloom measured on shoots defruited shortly after pollination. Return bloom in the small-fruited 'Gormely' was equally stimulated by removing fruit any time during ovule expansion. This result may indicate that early fruit removal is more important for large- than for small-fruited cultivars.

Two additional problems must be solved before pecan fruit thinning becomes commercially feasible. First, an economical thinning method must be developed, mechanical tree shaking has potential (Smith and Gallott, 1990). Second, we must determine the maximum fruit load a tree can bear without inducing yearly fluctuations in yield, kernel quality, and return bloom. Optimum fruit load most likely will vary with cultivar.

\section{Literature Cited}

Cochran, W.G. and G.M. Cox. 1957. Experimental designs. Wiley, New York.

Davis, J.T. and D. Sparks. 1974. Assimilation and translocationpatterns of carbon-14 in the shoot offruiting pecan trees, Carya illinoensis Koch. J. Amer. Soc. Hort. Sci. 99:468-480.

Lockwood, D.W. and D. Sparks. 1978. Translocationof ${ }^{14} \mathrm{Cin}$ 'Stuart'pecaninthe spring followingassimilationof ${ }_{1}^{4} \mathrm{CO}_{2}$ duringtheprevious growing season. J. Amer. Soc. Hort. Sci. 103:38-45.

Monselise,S.P.and E.E. Goldschmidt. 1982. Alternate bearing in fruit trees, p. 128-173. In: J. Janick (ed.). Horticulture reviews. vol. 4. AVI, Westport, Conn.

Reid,W.1986.Reasonsforpoorkernel tilling.Annu. Rpt. Northern Nut Growers Assn. 77:37-38.

Reid,W.1992a. Cold damage revisited. Kansas Nut Grower News 33(2):2.

Reid, W. 1992b. Growing pecan in Kansas. Kansas Coop. Ext. Serv. Misc. Factsheet 1025.

SAS Institute. 1988. SAS/STAT user's guide. version 6.03. SAS Institute, Cary, N.C.

Sitton, B.G. and F.N. Dodge. 1938. Growth and fruitingof three varieties of pecans on different seedling rootstock. Proc. Amer. Soc. Hort. Sci. 36:121-125.

Smith,M.W.andB.C.Cotten. 1985. Relationship of leaf elemental concentrations and yield to cold damage of 'Western' pecan. HortScience 20:420-422.

Smith, M.W. and J.C. Gallott. 1990. Mechanical thinning of pecan fruit. HortScience 25:414416.

Smith, M.W., R.W. McNew, P.L. Ager, and B.C. Cotten. 1986. Seasonal changes in the carbohydrate concentration in pecan shoots and their 


\section{Production and Culture}

relationship to flowering. J. Amer. Soc. Hort. Sci. 111:558-561.

Sparks, D. and C.E. Brack. 1972. Return bloom and fruit set of pecan from leaf and fruit removal. HortScience 7:131-132.

Taylor, G., G.V. Johnson, and M.W. Smith. 1992. Fertilizing pecan and fruit trees. Okla. State Univ. Ext. Facts 6232. von Broembsen, S., S. Coppock, and G. Taylor. 1992. Pecan insect and disease control-1992. Okla. State Univ. Current Rpt. 6209.

Williams, M.W. 1979. Chemical thinning of apples. Hort. Rev. 1:270-300.

Wood, B.W. 1986. Cold injury susceptibility of pecan as influenced by cultivar, carbohydrates, and crop load. HortScience 21:285-286.
Wood, B. W. 1989. Pecan production responds to root carbohydrates and rootstock. J. Amer. Soc. Hort. Sci. 114:223-228.

Wood, B.W. 1991. Alternate hearing of pecan, p. 180-190. In: B.W. Wood and J.A. Payne (eds.). Pecan husbandry: Challenges and opportunities. 1st Natl. Pecan Workshop Proc. U.S. Dept. of Agr., Agr. Res. Serv. 96. 